\title{
The Development of a Drawing Skills Training Model for Early Childhood Teachers

\author{
Minda Sari, Ardipal, Budiwirman
}

\begin{abstract}
One of the activities that can be done in improving the quality of Early Childhood or in Indonesia we called PAUD teachers is through drawing training. Teachers really need this skill training. Based on the results of interviews with a number of PAUD teachers in Padang City, it is known that PAUD teachers have very minimal drawing skills. Their students also really need drawing activities as a means and effort to foster creativity in fine arts. Drawing skills are a much-preferred area for developing children's spatial skills. Thys type of research was a Research and Development (R\&D) using instructional Model of ADDIE. This model encompassed of five phases, such as Analisys Phase, Design Phase, Development Phase, Implementation Phase, and Evaaluation Phase. The pictures are designed to train the teacher's hands in drawing, thereby making the teacher's wrists flexible. A flexible wrist makes for an attractive and creative image. Besides that, the pictures are designed to give the teacher a sensation when holding a pencil and scratching it onto the drawing paper.
\end{abstract}

Key words: training, skills, drawing

\section{I.INTRODUCTION}

The quality of teachers needs to be improved through training in order to expand the methods of teaching and mentoring children. This is because the teacher has a role as a motivator and evaluator, and sharpens knowledge and skills in directing children. This role cannot be replaced by anyone to form creative and character human resources. For this reason, improving the quality of teachers must start from the lowest level, namely early childhood education (PAUD) in terms of shaping children's character. The reason is, with good character or soft skills, Indonesian human resources will be able to compete and be accepted in the industrial world. One of the activities that can be carried out in improving the quality of PAUD teachers is through drawing training. Teachers really need this skill training. Based on the results of interviews with a number of PAUD teachers in Padang City, it is known that PAUD teachers have very little drawing skills. They really need drawing skills. Their students also really need drawing activities as a means and efforts to grow and develop children's character. Drawing skills are a much-preferred area for developing students' spatial skills [7]. The skills to draw and interpret graphics must be obtained at the previous teaching stage without having to be submitted to higher education) [2]

Revised Manuscript Received on December 05, 2020.

* Correspondence Author

Minda Sari*, Completing Doctoral Program in Education Science at Universitas Negeri Padang, Indonesia

Ardipal, Professor, Department of Language and Arts Faculty, Science Education of Padang State University, Indonesia

Dr. Budiwirman, Department of Language and Arts Faculty, Science Education of Padang State University, Indonesia

(c) The Authors. Published by Blue Eyes Intelligence Engineering and Sciences Publication (BEIESP). This is an open access article under the CC BY-NC-ND license (http://creativecommons.org/licenses/by-nc-nd/4.0/)
To develop students' drawing skills, a teaching curriculum is needed and must include a graphic curriculum that is constantly changing according to social and cultural needs [10].

The teacher must pay attention to the child's / student's drawing ability for the first year, compared to other materials. Because the ability to draw is a basic ability that a child/student must-have [4]. Hence, we need a training program that can fulfill the wishes of teachers to be skilled and creative in drawing. The teacher's creative ability in using many drawing methods greatly impacts the drawing ability of students in their class. [11]. Teacher training programs should use a concrete model to explore students' spatial abilities, especially drawing activities using isometric paper to improve their drawing skills [12] [9] [5] [13]. Using two-dimensional and three-dimensional objects will improve students' drawing skills and will help students identify visual objects [1] [3]. Besides the role of teachers, parents also have an extraordinary role in developing children's abilities, one of which is artistic abilities. Parents are also encouraged to have the ability to draw so that they can sharpen their children's abilities [6].

\section{II.METHOD}

The method in this research is the research and development (R\&D) with the ADDIE model (Analysis, Design, Development, Implementation, and Evaluation). At the analysis stage, several things are analyzed, namely needs analysis, curriculum analysis, task analysis, and teacher analysis. A needs analysis was carried out by interviewing PAUD teachers in Padang City to get information about the learning process they had done, especially in drawing lessons. The results of the preliminary analysis can be seen in the table below.

Table. 1. Summary of Preliminary Research

\begin{tabular}{|l|l|}
\hline \multicolumn{1}{|c|}{ Activity } & \multicolumn{1}{|c|}{ Focus } \\
\hline Analysis & $\begin{array}{l}\text { Needs analysis was aimed to obtain } \\
\text { information about drawing skills for } \\
\text { teachers and early childhood. }\end{array}$ \\
\hline $\begin{array}{l}\text { Curriculum } \\
\text { Analysis }\end{array}$ & $\begin{array}{l}\text { Curriculum analysis is carried out to } \\
\text { determine the assessment, content, and } \\
\text { teaching materials in the PAUD } \\
\text { curriculum. }\end{array}$ \\
\hline $\begin{array}{l}\text { Teachers } \\
\text { Analysis }\end{array}$ & $\begin{array}{l}\text { Teacher analysis was carried out to obtain } \\
\text { information about the teacher's ability to } \\
\text { draw. }\end{array}$ \\
\hline Task Analysis & $\begin{array}{l}\text { Task analysis was carried out to find out } \\
\text { what tasks can be applied so that they can } \\
\text { make teachers skilled in drawing. }\end{array}$ \\
& \\
$\begin{array}{l}\text { Published By: } \\
\text { Blue Eyes Intelligence Engineering } \\
\text { \& Sciences Publication } \\
\text { C Copyright: All rights reserved. }\end{array}$
\end{tabular}




\section{The Development of a Drawing Skills Training Model for Early Childhood Teachers}

\section{RESULT AND DISCUSSION}

\section{Need Analysis}

The survey results during the PAUD level drawing competition showed that early childhood children are not used to drawing activities. They were confused by all the drawing equipment that was given to him. Furthermore, it is also known that there is no PAUD teacher manual for teaching drawing material. Drawing material is still very rarely found and applied in learning to draw.

\section{Curriculum Analysis}

Based on a literature study conducted on the PAUD curriculum, it is known that there is no subject that specifically examines drawing skills. This has an impact on the continuity of learning in PAUD. Early Childhood is more directed towards coloring activities. From the results of the curriculum survey in tertiary institutions, the PAUD Study Program has not found any specific subjects that talk about drawing for early childhood.

\section{Teachers Analysis}

Based on the results of interviews with PAUD teachers in Padang City, it was found that PAUD teachers had very minimal skills in drawing. They can't draw well. So far, they only teach drawing instinctively. Without any basic skills in drawing. Pictures that are modeled on children are instant pictures, not pictures of their own creativity.

\section{Task Analysis}

A task analysis was carried out by observing and interviewing PAUD teachers in giving drawing lessons to children in their class. Based on these observations, it is known that PAUD teachers do not yet have a guidebook that applies to learning to draw. Even though drawing is one skill that early childhood teachers should have.

Early childhood teachers can get drawing skills with simple exercises. This activity must be done every day. There is no need for a special time to do this activity. It is enough to provide a sketchbook and use a variety of pencils. The variety of pencils used will increase the teacher's knowledge of how hard and thick they produce. There are pencils that produce thin, faint lines. There are also pencils designed to produce thicker, darker lines. To get the results of the training at the final stage which is more tangible, namely by no longer using a pencil, but by using a pen or marker, which if an error occurs in arranging various lines (exploration) cannot be erased or corrected, so it is repeated on another drawing paper. Additionally, according to this training principle which prioritizes repetitions, so that it becomes trained and skilled. After the sketchbook and pencil or pen are available, the next action is to draw various lines, circles, squares, triangles, and shading. The designed drawing consists of three parts. The first part is a drawing with simple, sparse lines. The second part is the middle part and begins to show a tight line portion. The last part is the tight part (bottom). The pictures used are as follows, adaptation from [8]

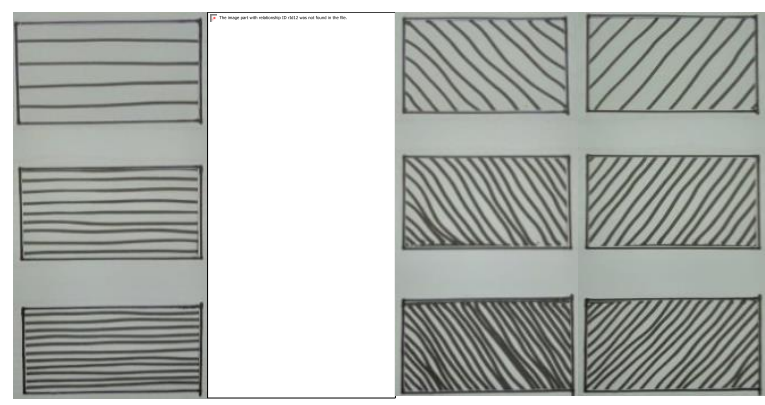

Figure 1. Various straight lines

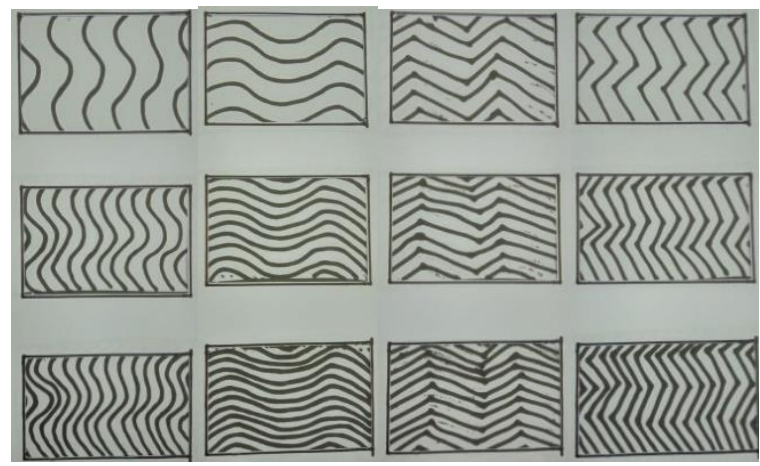

Figure 2. Various wavy lines and zigzag lines

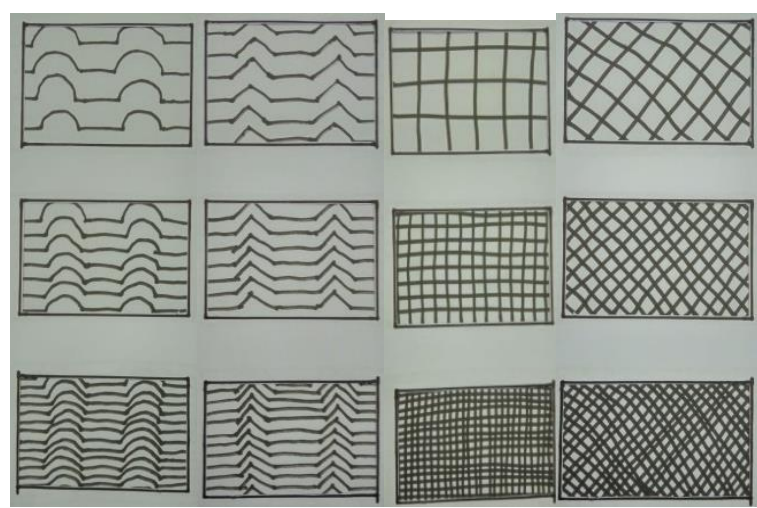

Figure 3. Variations of straight and curved lines

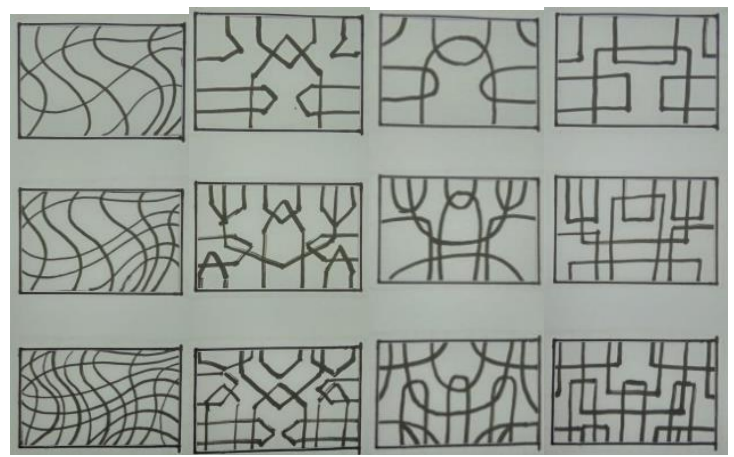

Figure 4. Variations of curved and square lines.

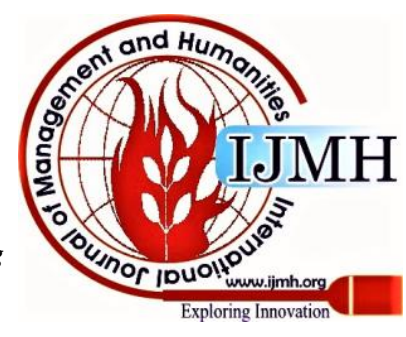



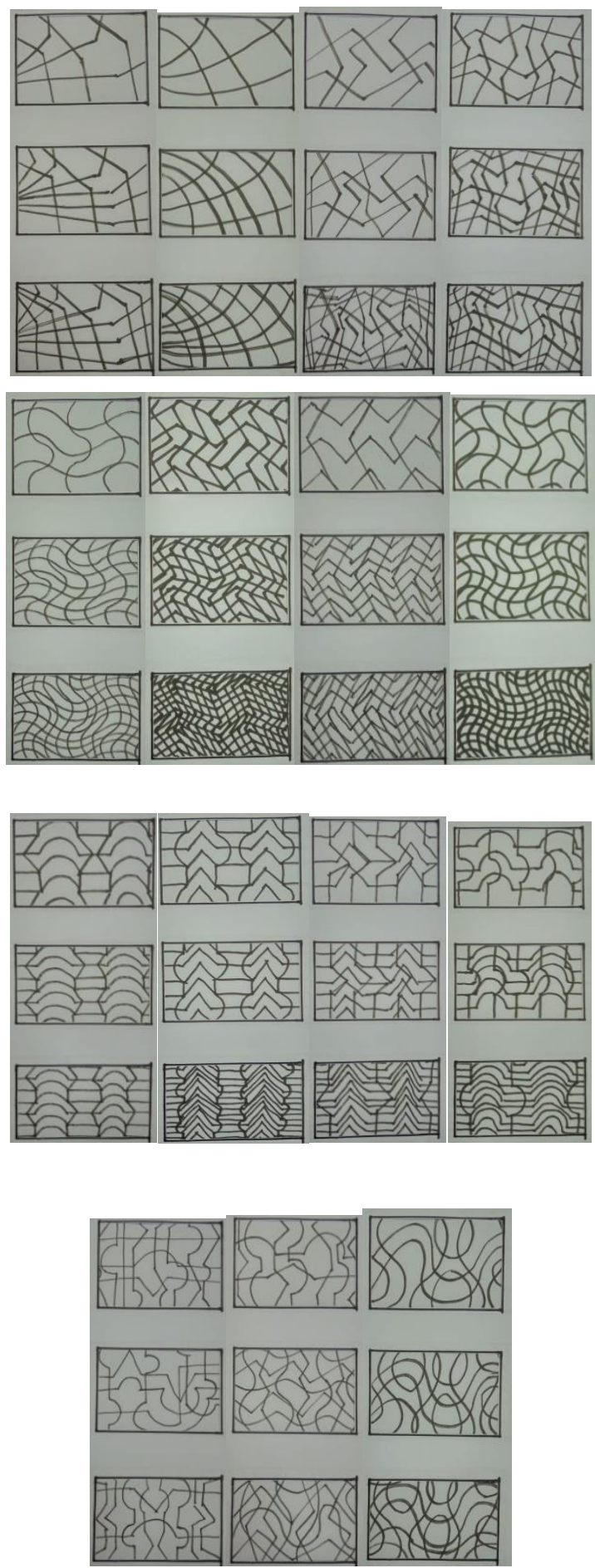

Figure 5. The various rhythms of drawing a line.

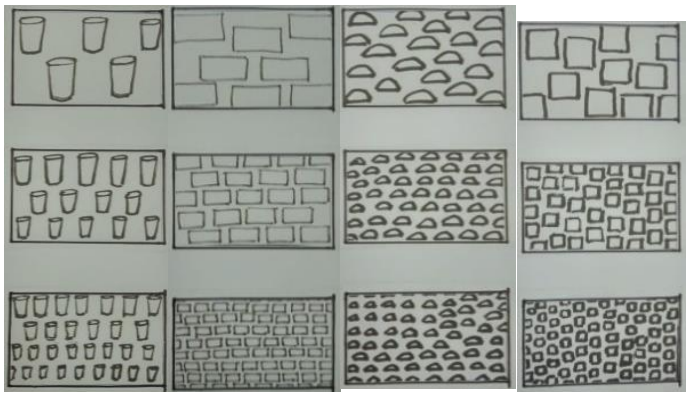

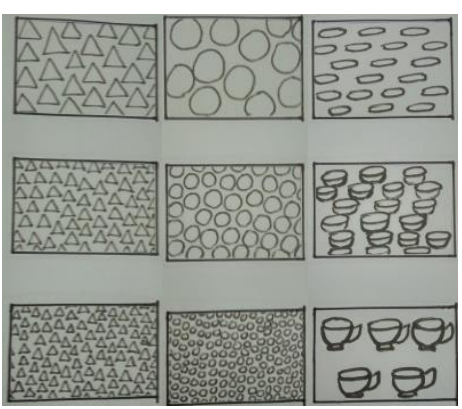

Figure 6. The shape of a square, semicircle, triangle and circle

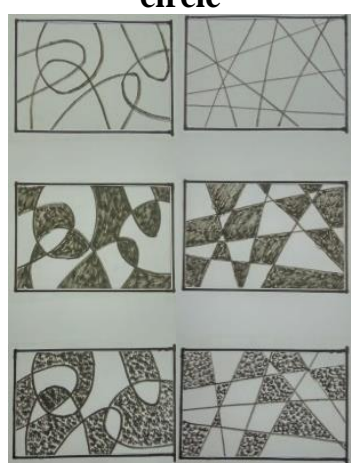

Figure 7. Creating a pattern and shading.

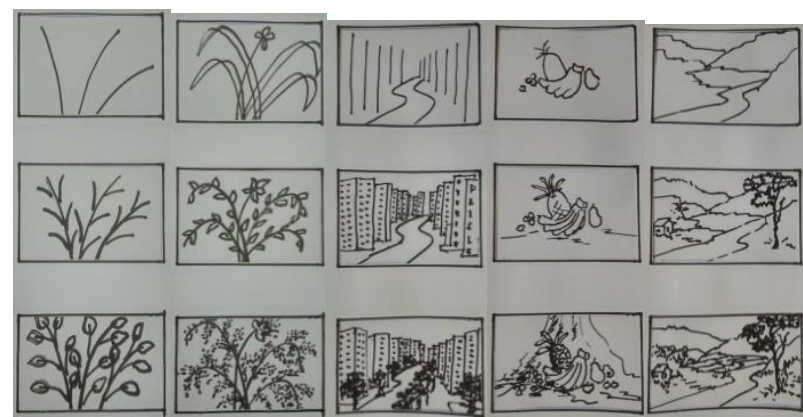

Figure 8. One of the outcomes of this training.

The pictures above are designed to train the teacher's hand in drawing. Besides that, the pictures are designed to give the teacher a sensation when holding a pencil and scratching it onto the drawing paper. As has been said before, the pencils used must vary. And the variations of the pencils used will give the teacher a sensation in scratching the pencil onto the drawing paper. Then, another, more important goal in this drawing exercise is to make the teacher's wrist flexible. Because basically everyone has the ability to draw lines, even drawing. The resulting lines and images vary. Some draw with rigid lines, and some with flexible lines. This happens because of the condition of a person's wrist. Everyone's wrist has a different wrist condition. There are flexible wrists and tense wrists. The wrist that is tense, will produce a rigid image. Meanwhile, a flexible wrist will produce an attractive and creative image. Likewise, with the teacher's condition. Not all teachers have flexible wrists. This is a significant problem for the teacher and will have an impact on the children's drawing skills in their class. For this reason, PAUD teachers need to do simple drawing exercises as described above, so that the PAUD teacher's wrists can become flexible.

Published By:

Blue Eyes Intelligence Engineering \& Sciences Publication

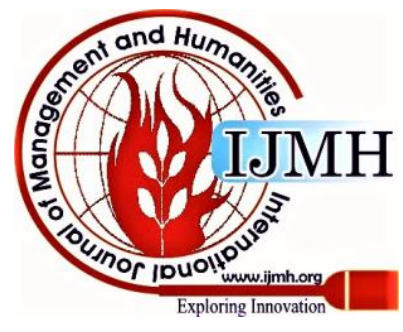


Exercise after practice which is carried out regularly will be able to make a person proficient in what field he is trained in [13]. Likewise withdrawing exercises. There are several advantages for the teacher in pursuing this practice. First, this exercise will make the teacher's wrists flexible. Second, this exercise will enrich the teacher's experience in drawing. A flexible wrist will create creative images. Coupled with the teacher's mastery of various pencils, it will produce more interesting and more creative drawings. If teachers can draw more interesting and creative, it is hoped that the ability of their students can also develop creativity in drawing at school.

\section{IV.CONCLUSION}

The practice of drawing lines, round shapes, rectangles will have a direct impact on the teacher's drawing skills. The more often they draw, the more flexible their wrists will be. Flexible wrists will produce attractive and creative images, which can bridge the children's artistic creativity abilities. For this reason, PAUD teachers must be able to provide examples of creative drawings so that they can be used as guidelines for Early Childhood in developing their creativity in drawing.

\section{ACKNOWLEDGEMENT}

Thank you very much to the lecturer promoter, Prof. Dr. Ardipal, M.Pd, and Dr. Budiwirman, M.Pd. thanks to his guidance and care, this article was finally completed. Thank you also to all the academicians of Padang State University who have helped a lot in completing this article. Once again, thank you so much.

\section{REFERENCES}

1. Abass, Bada Tayo, Bello Isyakka, Ijisakin Yemi Olaolu \& Fajuyigbe Michael Olusegun. (2014).Effects of Two and Three-Dimensional Visual Objects on the Acquisition of Drawing Skills among JSS1 Students in Osun State, Nigeria Department of Educational Technology, Obafemi Awolowo University, Ile- Ife, Nigeria 2 Department of Fine and Applied Arts, Obafemi Awolowo University, Ile-Ife, Nigeria. Online Published: February 11, 2014 doi:10.5430/wje.v4n1p62

http://dx.doi.org/10.5430/wje.v4n1p62

2. Aksoy, Bülent \& Remzi Namal (2020) Scope Validity of the Graph Drawing and Interpretation Skill Checklist Turkey Correspondence: Bülent Aksoy, Gazi Educational Faculty, Gazi University, Ankara, Turkey. International Education Studies; Vol. 13, No. 1; 2020 ISSN 1913-9020 E-ISSN 1913-9039 Published by Canadian Center of Science and Education

3. Arslan, Ali Riza and Dazkir, Sibel Seda. (2017). "Technical Drafting and Mental Visualization in Interior Architecture Education," International Journal for the Scholarship of Teaching and Learning: Vol. 11: No. 2, Article 15. Available at: https://doi.org/10.20429/ijsotl.2017.110215

4. Blackley, In G. Hin S., \& A. Cooke (Eds.). (2019).Preschoo Children's Drawings of 'Tall and Short' Jennifer Way University of Sydney. Mathematics Education Research: Impacting Practice (Proceedings of the 42nd annual conference of the Mathematics Education Research Group of Australasia) pp. 747-754. Perth: MERGA.

5. Gunbayi, Ilhan, Tayfun Yoruk, and Rabia Vezne. (2017).Improving Technical Drawing Skills of Vet Teachers: An Action Research Project. European Union Project Advisor Akdeniz University, Antalya, Turkey. IVETA.

6. Hsiao, Ching-Yuan. (2015).Current Kindergarten Parents' Attitudes toward and Beliefs about Children's Art Education in Majority Cities and Counties of Taiwan 1 Department of Early Childhood Education, National University of Tainan, Tainan, Taiwan. Online Published: March 29, 2015 doi:10.5539/ies.v8n4p80 URL: http://dx.doi.org/10.5539/ies.v8n4p80International Education Studies;
Vol. 8, No. 4; 2015 ISSN 1913-9020 E-ISSN 1913-9039 Published by Canadian Center of Science and Education

7. Kepceoğlu, İbrahim. (2018). Effect of Dynamic Geometry Software on 3-Dimensional Geometric Shape Drawing Skills Correspondence: İbrahim Kepceoğlu, Kastamonu University, Faculty of Education, Department of Science and Mathematics Education, Kastamonu, Turkey. Journal of Education and Training Studies Vol. 6, No. 10; October 2018 ISSN 2324-805X E-ISSN 2324-8068 Published by Redfame Publishing URL: http://jets.redfame.com

8. Marga, Try Edy. 2020. Mastering Pencil. Genta Group Production. Sidoarjo.

9. N, Cansiz., \& Cansiz, M. (2018). Enhancing Preservice Teachers' Observation and Inference Skills Nurcan CANSIZ Artvin Çoruh University, Faculty of Education, Department of Mathematics and Science Education Mustafa CANSIZ Artvin Çoruh University, Faculty of Education, Department of Mathematics and Science Education. İnönü University Journal of the Faculty of Education Vol 19, No 3, 2018 pp. 362-373 DOI: 10.17679/inuefd.335762

10. Övez1and, Filiz Tuba Dikkartin \& NazlıAkar. (2018) Anthropological analysis of content knowledge of preservice elementary mathematics teachers' on graphs Department of Mathematics Education, Necatibey Education Faculty, Balikesir University, Turkey. Vol. 13(8), pp. 281-306, 23 April, 2018 DOI: 10.5897/ERR2018.3506 Article Number: 28B85DE56798 ISSN 1990-3839 Copyright (C) 2018 Author(s) retain the copyright of this article http://www.academicjournals.org/ERR

11. Schoff, Susannah. (2016). The Creative Teacher: Learning From Psychology and Art Education to Develop Our Creative Processes in Teaching English to Speakers of Other Languages Academy of Art University, San Francisco. The CATESOL Journal 28.2

12. Toptasa, Veli \& Elif Tugçe Karacaa. (2017). An Analysis of Preservice Elementary School Teachers' Skills in Geometrical Drawing Using Isometric Paper Received: 2 September 2017 Revised: 10 October 2017 Accepted: 18 October 2017 ISSN: 1307-9298 Copyright (C) IEJEE www.iejee.com DOI: 10.26822/iejee.2017236126.

13. Zamil, Ilham. (2019). The Model Development of Minangkabau Songket Weaving Training. International Journal of Scientific \& Technology Research Volume 8, Issue 11 November 2019. ISSN 2277-8616. IJSTR

\section{AUTHORS PROFILE}

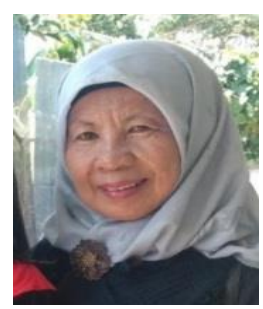

Minda Sari, The author was born in Padang Panjang, West Sumatra on August 7, 1952. Taught at the Fine Arts Middle School (SMSR) from 1978 to 1994. Served as chairman of the painting department from 1988 to 1994. The author also taught at the handicraft industry secondary school or used to called SMIK (today SMK Negeri 8 Padang) from 1994 to 2012. At this school the author was also the head of the textile department from 1994 to 1997. In addition to teaching actively as deputy chairman of the fine arts commission of the Padang Arts Council from 2004 to 2009. Since the year of 2012 is undergoing retirement.And during retirement, the author actively participated in painting exhibitions in West Sumatra.Currently completing doctoral program in education science at Universitas Negeri Padang.

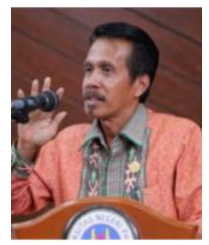

Name :Ardipal, Professor, Departement: Language and Arts Faculty: Science Education of Padang State University Expert: Pedagogy. Beliaupernahmenjabatsebagaivice Rector UNP selamaduaperiodeyakni pada tahun 2012-2016 dan periode 2016-2020.

Papers:

1. The Development of Batik Training Model for Transformation of Minangkabau Carving Into Batik Design Based on Local Culture

2. Improving the Quality of Early Childhood Teachers in the Development of Quality Human Resources in the Future

3. Optimizing the Role of Educators and Students in Learning Arts 
4. The Ideal Cultural Arts Education Curriculum for Students in the Future

5. Humanist Art Education with Educational Renewal and Learning through Planting the Four Pillars of Education

6. Talempong Kreasi, Minangkabau Traditional Music Modernization

7. Development of Music Art Teaching Materials Based on Contextual Learning

8. The Talempong Musical Creations: Effort to Preverse the Minangkabau Traditional Music

9. Utilizing Music in Sport and Exercise at Elementary School in Indonesia

10. Character Development Problems through Art Education in Elementary Schools

11. Restore Indonesian Children's Songs: An Analysis of Music Structure

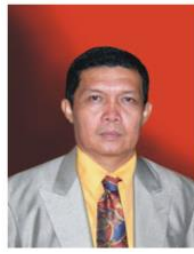

\section{Nama : Budiwirman \\ Titel : : Doctor}

Departement: Language and Arts Faculty: Science Education of Padang State University Expert: Pedagogy

Tulisan :

1. The Model Development of Minangkabau Songket Weaving Training.

2. Creative Economy/Creative Industry Development in Indonesia

3. Documentary Film Silungkang Songket Making

4. Designing a Visual Identity Ale-Ale "Pak In" Typical of Sawahlunto City.

5. Website Designing Typical Minangkabau Traditional Food Recipes.

6. Documentary Video Heritage of Bukittinggi Pasar Seken.

7. The design of the Harau Valley Nature Tourism Logo in Fifty Cities District.

8. Songket Hermeneutics as Traditional Clothing in the Perspective of Minangkabau Culture.

9. Analysis of the Functions and Meanings of Suntiang in Traditional Minangkabau Clothing

10. Form and Function of Hajj Tale in the Event of Releasing Hajj Pilgrims in Pondok Agung Village, Pondok Tinggi District, Sungai Penuh City.

11. Analysis of The Symbolic Meaning and Cultural Identity in Sarolangon Batik Arts Jambi Province

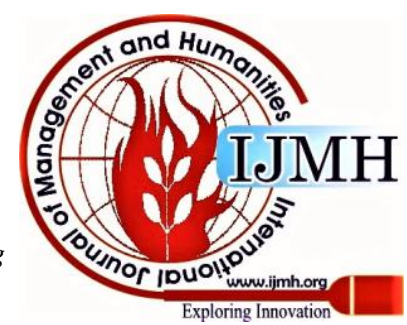

